\title{
Influence of Laser Shock Peening Surface Treatment on Fatigue Endurance of Welded Joints from S355 Structural Steel
}

Ján Lago ${ }^{1}$, Mario Guagliano ${ }^{2}$, František Nový ${ }^{1,3}$, Otakar Bokůvka ${ }^{1,3}$

${ }^{1}$ University of Žilina, Faculty of Mechanical Engineering, Department of Materials Engineering, Univerzitná 8215/1, 010 26 Žilina. E-mail: jan.lago@fstroj.uniza.sk, otakar.bokuvka@fstroj.uniza.sk

${ }^{2}$ Politecnico di Milano, Department of Mechanical Engineering, Via La Masa 1, 20156 Milano. E-mail: mario.guagliano@polimi.it

${ }^{3}$ Research Centre of University of Žilina, Univerzitná 8215/1, 01026 Žilina. E-mail: frantisek.novy@ fstroj.uniza.sk

This work deals with fatigue testing of the EN S355 structural steel welded joint. The weld was manufactured by the MIG welding technology and as the filler material was used the G3Si1 wire. The fatigue tests were carried out in the rotating bending mode on the specimens manufactured from the welded joint of the S355 steel. The main aim was to evaluate the fatigue endurance of the weld material and for this reason were used machined axis symmetrical specimens to remove the notch effect of the weld shape. In order to increase the fatigue endurance of the weld, the Nd-YAG laser was used for laser shock peening (LSP) of specimens surfaces, which lead to removing of the weld defects but in overall caused that LSP has behaved as the notch and lead to decreasing of the fatigue endurance. Obtained results of fatigue tests are compared, discussed and supported by correlation with results of additional experiments, e.g. identification of incurred structures after the laser shock peening by the metallographic observations and micro-hardness tests.

Keywords: S355, fatigue, laser shock peening.

\section{Acknowledgment}

The research was supported by European regional development fund and Slovak state budget by the project "Research Centre of University of Žilina”, ITMS 26220220183 (40\%), Scientific Grant Agency of the Ministry of Education, Science and Sports of the Slovak Republic and Slovak Academy of Sciences, grant No.: 1/0123/15 (30 \%) and by the project APVV 14-0096 (30\%).

\section{References}

[1] MICHALEC, I., MARÔNEK, M., BÁRTA, M., NOVÝ, F. (2012). Weld joints fatigue properties of thin carbon steel sheet treated by nitrooxidation. Tehnički vjesnik. Vol. 19. No. 1, pp. 65-69. ISSN 1330-3651.

[2] MAZUR, M., ULEWICZ, R., BORKOWSKI, S. (2012). Properties of steel used in the production of semi-trailers car. In. Zb. SEMDOK, 17 $7^{\text {th }}$ Žilina, University of Žilina, p. 81-84, ISBN 978-80-554-0477-6.

[3] ULEWICZ, R., MAZUR, M., SZATANIAK, P. (2012). Fatigue properties of selected grades of steel used for main components of semitrailers and agricultural machines. In. Proc. $29^{\text {th }}$ international colloquium: Advanced Manufacturing and Repair Technologies in Vehicle Industry, Žilina - Terchová, EDIS ŽU Žilina, pp. 58-63, ISBN 978-80-554-0533-9.

[4] VRZGULA, P., FATURÍK, M. (2014). New inspection technologies for identification of failure in the materials and welded joints for area of gas industry. Manufacturing Technology, Vol. 14, No. 3, pp. 487-492, ISSN 12132489.

[5] KONAR, R., MICIAN, M., HLAVATY, I. (2014). Defect detection in pipelines during operation using magnetic flux leakage and phased array ultrasonic method. Manufacturing Technology, Vol. 14, No. 3, pp. 337-341, ISSN 1213-2489.

[6] DOPJERA, D., KONAR, R., MICIAN, M. (2014). Ultrasonic testing of girth welded joint with TOFD and phased array. Manufacturing Technology, Volume 14, Issue 3, Pages 281-286, ISSN 1213-2489.

[7] MESKO, J., ZRAK, A., MULCZYK, K., TOFIL, S. (2014). Microstructure analysis of welded joints after laser welding. Manufacturing Technology, Vol. 14, No. 3, pp. 355-359, ISSN 1213-2489.

[8] RADEK, N., MESKO, J., ZRAK, A. (2014). Technology of laser forming. Manufacturing Technology, Vol. 14, No. 3, pp. 428-431, ISSN 1213-2489.

[9] ZRAK, A., KONAR, R., JANKEJECH, P. (2015). Influence of chemical composition in steel on laser cutting stability, Manufacturing Technology, Vol. 15, No. 4, pp. 748-752, ISSN 1213-2489. 
[10]YOU, L., LIQUN, L., LINA, S. (2015). Effect of shot peening on the fatigue resistance of laser surface melted 20CrMnTi steel gear. Material science and engineering A, Vol. 629, pp.8-15, ISSN: 0921-5093.

[11]CHANG, Y., YILIANG, L., SUSLOVB, S., DONG, L., GARY, J. C. (2014). Ultrahigh dense and gradient nanoprecipitates generated by warm laser shock peening for combination of high strength and ductility. Materials Science \& Engineering A, Vol. 609,pp. 195-203, ISSN: 0921-5093

[12]LIUCHENG, Z., WEIFENG, H., SIHAI, L., CHANGBAI, L., CHENG, W., XIANGFAN, N. GUANGYU, H. XIAOJU S. YINGHONG, L. (2016). Laser shock peening induced surface nanocrystallization and martensite transformation in austenitic stainless steel. Journal of Alloys and Compounds, Vol. 655, pp. 66-70, ISSN: 09258388.

[13]SHADANGI, Y., CHATTOPADHYAY, K., RAI, S.B., SINGH, V. (2015). Effect of LASER shock peening on microstructure, mechanical properties and corrosion behavior of interstitial free steel. Surface \& Coatings Technology, Vol. 280, pp. 216-224, ISSN: 0257-8972.

[14]GANESH, P., SUNDAR, R., KUMAR, H., KAUL, R., RANGANATHAN, K., HEDAOO, P., RAGHAVENDRA, G., ANAND KUMAR, S., TIWARI, P., NAGPURE, D.C., BINDRA, K.S., KUKREJA, L.M., OAK, S. M. (2014). Studies on fatigue life enhancement of pre-fatigued spring steel specimens using laser shock peening. Materials and Design, Vol. 54, pp. 734-741, ISBN: 978-0-08-098205-2.

[15]LAGO, J., BOKUVKA, O., NOVY, F. (2015). The weld toe improvement of Domex 700 by laser remelting. Materials today: Proceeding, (in press), ISSN: 2214-7853.

[16]MARKOVICOVA, L., HURTALOVA, L., ZATKALIKOVA, V., GARBACZ, T. (2014). Evaluation of composite structures by light microscopy and image analysis. Manufacturing Technology, Vol. 14, No. 3, pp. 351-355, ISSN 1213-2489. 